\title{
Analisis Hukum dan Akibatnya Terhadap Pengalihan Hak Atas Harta Warisan Tanpa Persetujuan Seluruh Ahli Waris (Studi Kasus Putusan Pengadilan Negeri Kolaka Nomor 17/Pdt.G/2017/PN KKA)
}

\author{
Legal Analysing and Implicating toward Expropriation of Bequest \\ Without Beneficiary Agreement \\ (A Case Study in the Court of Kolaka registered Number \\ 17/Pdt.G/2017/PN KKA)
}

\author{
Nur Aliyah \\ Universitas Sembilanbelas November Kolaka \\ E-mail: aliyaharnanda@gmail.com \\ Muhammad Sjaiful \\ Pascasarjana Universitas Halu Oleo \\ E-mail: hamadsaiful@yahoo.com \\ Sukring \\ Pascasarjana Universitas Halu Oleo \\ E-mail: sukring_69@yahoo.co.id
}

\begin{abstract}
This article addressed at analyzing expropriation of bequest without beneficiary agreement in accordance of Private Law (Burgerlijk Wetbook) as registered 17/Pdt.G/2017/PN Kka. Besides, this study is examining the protection of heir-at-law that based on verdict of Kolaka Court. This research applied legal analysis. This analysing revealed that certainly and systematically was decided legitimacy of expropriation of bequest without beneficiary agreement based on verdict of 17/Pdt.G/2017/PN Kka. This case was initially from one of heir-at-law, Muhammad Aliyas Nokke who was intentionally committed to register the land registration without beneficiary agreement. Thus, the other heirs were suing to the Judge. Eventually the court decided that the others have actually legitimacy the land registration. And the loser, Muhammad Aliyas Nokke was claimed as paradoxically went against the rules. The court decided confiscated the land registration as an object of legal action and considered has a legitimate and valuable.
\end{abstract}

Keywords: Transfer of Inheritance, Approval; Heir

Abstrak: Penelitian ini bertujuan untuk menganalisis pengalihan Harta Warisan tanpa persetujuan seluruh Ahli Waris sah menurut Hukum Perdata (BW) dan menelaah hukum melindungi hak-hak Ahli Waris berdasarkan Putusan Pengadilan 
Negeri Kolaka Nomor: 17/Pdt.G/2017/PN Kka. Metode penelitian ini bersifat preskripsi analisis. Dari penelitian ini diperoleh gambaran secara rinci dan sistematis tentang keabsahan pengalihan hak atas Harta Warisan tanpa persetujuan seluruh Ahli Waris menurut Hukum Perdata (BW) serta Putusan Pengadilan Negeri Kolaka Nomor: 17/Pdt.G/2017/PN Kka. Berdasarkan kasus yang telah diputus di Pengadilan Negeri Kolaka Nomor: 17/Pdt.G/2017/PN Kka. Kronologi perkara adalah salah seorang ahli waris melakukan balik nama Sertifikat Hak Milik Nomor 210 yang merupakan harta warisan milik bersama tanpa sepengetahuan ahli waris yang lain. Ahli waris yang merasa dirugikan mengajukan gugatan ke Pengadilan Negeri Kolaka dan gugatan Para Penggugat diterima, yang menyatakan bahwa balik nama Sertifikat hak Milik atas nama Nokke menjadi Muh. Aliyas Nokke adalah tidak sah dan merupakan Tindakan Melawan Hukum. Hakim menetapkan bahwa Para Penggugat adalah benar merupakan Ahli Waris dari Nokke, serta sita jaminan yang diletakkan oleh Pengadilan Negeri Kolaka atas obyek sengketa adalah sah dan berharga.

Kata kunci: Pengalihan Harta Warisan, Persetujuan; Ahli Waris

\section{PENDAHULUAN}

Hukum Waris adalah salah satu bagian dari Hukum Perdata secara keseluruhan dan merupakan bagian terkecil dari Hukum Keluarga. Hukum Waris yang berlaku di Indonesia masih bersifat pluralistis artinya masih berlaku beberapa sistem hukum yang mengaturnya (legalitas formal). Ada tiga sistem Hukum Waris yang berlaku di Indonesia yaitu:

1) Sistem Hukum Waris Perdata Barat yang diatur dalam Kitab Undang-Undang Hukum Perdata Indonesia.

2) Sistem Hukum Waris Adat yaitu hukum kewarisan yang beraneka sistemnya karena dipengaruhi oleh bentuk etnis di lingkungan hukum adatnya, yang dikenal dengan sistem kewarisan matrilineal (sistem pewarisan yang menarik garis keturunan ibunya), sistem patrilineal (sistem pewarisan yang menarik garis keturunan ayahnya), sistem bilateral (sistem pewarisan yang menghubungkan dirinya baik dari keturunan ibunya maupun ayahnya). ${ }^{1}$

3) Sistem Hukum Waris Islam yang berlaku bagi Warga Negara Indonesia yang beragama Islam dan Kompilasi Hukum Islam yang terbit sesuai Instruksi Presiden Nomor 1 Tahun 1991 pada tanggal 10 Juni 1991 yang dijadikan sebagai pedoman landasan Pengadilan Agama dalam memutuskan seputar kewarisan, wakaf dan perkawinan.

Terjadinya pemberlakuan berbagai macam Hukum Waris disebabkan kebutuhan masyarakat pada zamannya dalam merespons berbagai macam kepentingan yang dihadapinya kemudian secara legalitas formalnya masih dibenarkan secara konstitusi Negara atas pemberlakuannya sampai saat ini dan belum terjadi Unifikasi Hukum terkait

1 Maman Suparman, Hukum Waris Perdata, Jakarta: Sinar Grafika, 2015, hlm. 5. 
dengan Hukum Waris, untuk dapat memenuhi kebutuhan hukum masyarakat Indonesia saat ini dan saat yang akan datang dalam rangka pembangunan masyarakat yang adil dan makmur berdasarkan Pancasila dan Undang-Undang Dasar $1945^{2}$

Beralihnya seluruh kekayaan baik aktiva maupun passiva dengan sendirinya karena Hukum Waris mengenal asas saisine, dan dengan beralihnya seluruh harta kekayaan milik peninggal harta kepada Ahli Waris maka penyelesaian atas harta tersebut wajib dilakukan segenap Ahli Waris secara bersama-sama sesuai dengan asas kebersamaan, sebab segenap Ahli Waris pada hakikatnya merupakan personifikasi dari peninggal harta itu sendiri.3. Hal yang penting dalam masalah harta warisan adalah bahwa pengertian warisan itu masih memperlihatkan adanya tiga unsur essential (mutlak) yaitu:4

1) Seorang peninggal warisan yang pada wafatnya meninggalkan harta kekayaan.

2) Seseorang atau beberapa orang penerima warisan yang berhak menerima kekayaan yang ditinggalkan.

3) Harta warisan atau harta peninggalan yaitu kekayaan (in concreto) yang ditinggalkan dan sekali beralih pada Ahli Waris tersebut.

Hakikatnya Hukum Waris bertujuan untuk mengatur pembagian harta warisan kepada para Ahli Waris, agar tidak terjadi perselisihan ketika harta warisan dibagikan. Jadi Hukum Waris adalah soal apakah dan bagaimanakah berbagai hak dan kewajiban atas harta seseorang pada waktu ia meninggal dunia akan beralih kepada orang lain yang masih hidup. ${ }^{5}$

Salah satu contoh kasus yang terjadi yaitu antara nyonya MR sebagai penggugat 1 , tuan $\mathrm{AB}$ sebagai penggugat II, nyonya $\mathrm{MH}$ sebagai penggugat III, nyonya MD sebagai penggugat IV, tuan MA sebagai penggugat V, dengan nyonya KM sebagai tergugat 1 , tuan PN sebagai tergugat II, Kepala Desa Watalara sebagai turut tergugat 1, Kepala Badan Pertanahan Nasional Kolaka sebagai turut tergugat II. Bahwa yang menjadi pokok permasalahannya adalah penggugat 1 , II, III, IV dan V mengajukan gugatan kepada para tergugat yang diduga telah melakukan perbuatan melawan hukum, karena telah melakukan balik nama Sertifikat Hak Milik Nomor: 210, dari almarhum NK menjadi almarhum M.AN

\footnotetext{
H. Hilman Hadikusuma, Hukum Waris Adat, Bandung: PT. Citra Bakti, 2003, hlm. 1.

Syahril Sofyan, Beberapa Dasar Teknik Pembuatan Akta (Khusus Warisan), Medan: Pustaka Bangsa Press, 2011, hlm. 4.

4 Wignjodipuro Surojo, Pengantar dan Azas-Azas Hukum Adat, Bandung: Alumni, 1973, hlm. 191.

5 Prodjodikoro Wiryono. R, Hukum Waris di Indonesia, Bandung: Sumur Bandung, 1983, hlm. 13.
} 
tanpa sepengetahuan dan persetujuan dari para penggugat sebagai pihak yang turut menjadi Ahli Waris yang sah dari almarhum NK.

Permasalahan yang muncul karena para penggugat beranggapan bahwa mereka (para penggugat) berhak atas harta warisan dari almarhum NK dikarenakan para penggugat juga merupakan anak kandung dari almarhum NK. Para tergugat dan turut tergugat diduga mengaburkan bukti-bukti bahwa para penggugat adalah juga Ahli Waris yang sah dari almarhum NK.

Para penggugat baru mengetahui bahwa Sertifikat Hak Milik Nomor: 210 tersebut telah beralih kepemilikan berdasarkan pewarisan dari almarhum NK kepada almarhum M.AN, setelah ada pihak yang menyatakan diri sebagai pemenang lelang atas tanah dan bangunan Sertifikat Hak Milik Nomor: 210 atas nama almarhum M.AN dari PT Permodalan Nasional Madani (Persero), PNM ULaMM (Unit Layanan Modal Mikro) yang merupakan layanan pembiayaan dan pendampingan usaha kepada pelaku usaha mikro dan kecil (UMK). Para Penggugat menyatakan tidak pernah memberikan/diminta persetujuan atas peralihan Sertifikat Hak Milik Nomor: 210. Keyakinan ini menjadi dasar argumentasi para penggugat bahwa para pihak yang menjadi tergugat pada kasus ini telah melakukan pengaburan buktibukti bahwa almarhum M.AN bukan satu-satunya Ahli Waris dari almarhum NK tapi para penggugat juga merupakan Ahli Waris yang sah dari almarhum NK berdasarkan Putusan Pengadilan Agama Kolaka Kelas II Nomor: 0021/Pdt.P/2017/PA Klk, pada Tanggal 17 April 2017.

Berdasarkan uraian di atas penulis tertarik untuk menelaah lebih lanjut mengenai Pengalihan Harta Warisan oleh seseorang tanpa persetujuan semua pewaris yang sah. Berdasarkan permasalahan yang telah diuraikan di atas, maka tujuan yang hendak dicapai dalam penelitian ini adalah untuk menganalisis keabsahan kepemilikan hak atas benda tetap yang diperoleh berdasarkan waris tanpa persetujuan sebahagian Ahli Waris. Selain itu, penelitian ini juga dilakukan untuk menelaah bagaimana hukum melindungi hak-hak Ahli Waris terhadap pengalihan Harta Warisan tanpa persetujuan seluruh Ahli Waris.

\section{METODE PENELITIAN}

Tipe penelitian yang digunakan yaitu penelitian hukum yang bersifat Normatif, yang merupakan suatu proses untuk menemukan aturan hukum, prinsip-prinsip hukum, maupun doktrin-doktrin hukum guna menjawab isu hukum yang dihadapi yang menghasilkan argumentasi, teori dan konsep baru sebagai preskripsi dalam menyelesaikan 
masalah yang dihadapi. 6 Dengan pendekatan penelitian yaitu Pendekatan Undang-Undang (Statute approach), Pendekatan Konseptual (Conceptual approach), Pendekatan Kasus (case approach). Sedangkan sumber bahan hukum yang digunakan adalah bahan hukum primer dan sekunder (studi kepustakaan), dengan analisis yang sifatnya preskripsi.

Sasaran penelitian ini adalah hukum atau kaidah (norm). Pengertian kaidah meliputi asas hukum, kaidah dalam arti sempit (value), peraturan hukum konkret. Penelitian yang berobjekkan hukum normatif berupa asas-asas hukum, sistem hukum, taraf sinkronisasi vertikal dan horizontal. ${ }^{7}$

Spesifikasi penelitian dalam penulisan bersifat deskriptif analisis, yaitu dari penelitian ini diharapkan diperoleh gambaran secara rinci dan sistematis tentang permasalahan yang akan diteliti. Analisis dilakukan berdasarkan gambaran, fakta yang diperoleh dan akan dilakukan secara cermat bagaimana menjawab permasalahan dalam menyimpulkan suatu solusi sebagai jawaban dari permasalahan tersebut. ${ }^{8}$

\section{ANALISIS DAN PEMBAHASAN}

\section{Kepastian Hukum dalam Hukum di Indonesia}

Negara Republik Indonesia sebagai Negara hukum berdasarkan Pancasila dan UndangUndang Dasar Negara Republik Indonesia Tahun 1945 menjamin kepastian, hukum bagi setiap warga Negara. Kepastian hukum menunjuk kepada pemberlakuan hukum yang jelas, tetap, konsisten, dan konsekuen, yang pelaksanaannya tidak dapat dipengaruhi oleh keadaan-keadaan yang sifat subjektif. Indikator adanya kepastian hukum di suatu negara itu sendiri adalah adanya peraturan perundang-undangan yang jelas dan perundang-undangan tersebut diterapkan dengan baik oleh hakim maupun petugas hukum lainnya.

Legitimasi hukum terhadap kekuasaan, berarti menetapkan keabsahan kekuasaan dari aspek yuridisnya. Setiap kekuasaan yang memiliki landasan hukum secara formal berarti memiliki legalitas atau legitimasi ${ }^{9}$. Vant Kan berpendapat bahwa tujuan hukum adalah menjaga setiap kepentingan manusia agar tidak diganggu dan terjamin kepastiannya ${ }^{10}$.

Kepastian hukum memang bukan satu-satunya dan juga tidak dapat berdiri sendirinya, namun dengan mengetahui hak dan kewajiban masing-masing yang diatur

\footnotetext{
Peter Mahmud Marzuki, Penelitian Hukum, Jakarta: Kencana Group, 2005, hlm. 35.

Soerjono Soekanto dan Sri Mamudji, Penelitian Normatif, UII Perss, Jakarta: 2001, hlm.70.

8 Ibid., hlm. 30.

9 Muhammad Sjaiful, Wajah Politik Hukum Indonesia, Kendari: Komunika, 2014, hlm. 55.

10 Jonathan Sarwono, Metode Penelitian Kuantitatif dan Kualitatif, Yogyakarta: Graha Ilmu, 2006, hlm. 74.
} 
dalam hukum sangat dimungkinkan tidak terjadi sengketa ${ }^{11}$, seperti yang terjadi pada pendekatan kasus dalam penelitian ini. Apabila kepastian hukum yang dijadikan sasaran, maka hukum formal adalah wujud yang dapat diambil sebagai tolak ukurnya, dengan demikian perlu mengkaji hukum formal sebagai basis dalam menganalisis suatu kebijakan yang dapat memberikan suatu kepastian hukum.

Demikian juga ketentuan pasal 19 Ayat (2) UUPA menegaskan bahwa pemberian surat tanda bukti hak (sertifikat) yang berlaku sebagai alat pembuktian yang kuat, ini sesuai pula dengan penjelasan atas UUPA Bab IV alinea 2 yang menyebutkan pendaftaran tanah yang bersifat rechtkadaster yang artinya bertujuan menjamin kepastian hukum. Kepastian hukum sertifikat seharusnya dapat dipahami sebagai sertifikat yang merupakan produk dari lembaga pemerintah adalah sesuatu sebagai alat bukti kepemilikan hak atas tanah yang tidak dapat diganggu gugat lagi. Akan tetapi sebagaimana penjelasan pasal 32 Ayat (1) PP No. 24 Tahun 1997 sertifikat merupakan tanda bukti yang kuat selama tidak dapat dibuktikan sebaliknya data fisik dan data yuridis yang tercantum di dalamnya diterima sebagai data yang benar.

Kepastian hukum menurut pendapat Jan Michiel Otto dalam bukunya Adrian Sutendi, bahwa untuk menciptakan kepastian hukum harus memenuhi syarat-syarat sebagai berikut:

a) Ada aturan hukum yang jelas dan konsisten;

b) Instansi pemerintah menerapkan aturan hukum secara konsisten, tunduk dan taat terhadapnya;

c) Masyarakat menyesuaikan perilaku mereka terhadap aturan hukum tersebut;

d) Hakim-hakim yang mandiri, tidak berpihak dan harus menerapkan aturan hukum secara konsisten serta jeli sewaktu menyelesaikan sengketa hukum;

e) Putusan pengadilan secara konkret dilaksanakan.12

\section{Upaya dan Perlindungan Hukum Terhadap Pengalihan Harta Warisan Tanpa Persetujuan}

Berdasarkan hasil wawancara penulis dengan para nara sumber, yakni para pihak Penggugat dalam hal ini Para Ahli Waris. Bahwa, Sertifikat Hak Milik Nomor 210 atas nama

11 Muhammad Yamin, Beberapa Dimensi Filosofi hukum Agraria, Medan, Pustaka Bangsa Perss, 2003, hlm. 41-42.

12 Adrian Sutedi, Sertifikat Hak Atas Tanah, Jakarta: Sinar Grafika, 2011, hlm. 27. 
Nokke dengan luas 2000 M2 berlokasi di Dusun 1, Desa Watalara, Kecamatan Baula, Kabupaten Kolaka adalah milik Nokke dan Sitti Aminah yang merupakan Orang Tua dari para Penggugat. Nokke dan Sitti Aminah keduanya telah meninggal dunia dan memiliki enam (6) orang anak sebagai Ahli Waris. Satu dari keenam anaknya yaitu Muh. Aliyas Nokke juga telah meninggal dunia. Objek sengketa berupa Sertifikat Hak Milik Nomor 210 dan Rumah di atasnya di tempati oleh Muh. Aliyas Nokke beserta anak dan istrinya. Sebelum dan setelah orang tua mereka meninggal Objek sengketa berupa Sertifikat Hak Milik Nomor 210 dan Rumah di atas tanah tersebut masih atas nama Nokke dan dalam penguasaan Para Penggugat (Ahli Waris). Namun, setelah Muh. Aliyas Nokke meninggal dunia Para Penggugat baru mengetahui ternyata tanah Sertifikat Hak Milik Nomor 210 milik orang tua mereka telah di balik nama dari Nokke menjadi Muh. Aliyas Nokke.

Maka pada tanggal 07 Maret 2017 Para Penggugat mengajukan permohonan ke Pengadilan Agama yang telah terdaftar pada Kepaniteraan Pengadilan Agama Kolaka dalam register dengan Nomor 0021/Pdt.P/2017/PA Klk tanggal 08 Maret 2017 mengajukan halhal sebagai berikut:

1) Bahwa Nokke bin Taibe menikah dengan perempuan bernama Sitti Aminah binti Lambaga dan telah di karuniai 6 orang anak bernama:
a) Hj. Mariati binti Nokke, Umur 52 tahun;
b) Abbas bin Nokke, Umur 49 tahun;
c) Marhaeni binti Nokke, Umur 47tahun;
d) H. Muh. Aliyas Nokke bin Nokke, Umur 45 tahun;
e) Hj. Mardania binti Nokke, Umur 44 tahun;
f) H. Muh. Amin bin Nokke, Umur 40 tahun;

2) Bahwa Nokke bin Taibe telah meninggal dunia pada tanggal 03 Oktober 2003 berdasarkan Surat Keterangan Meninggal Dunia Nomor: 470/92/2017 yang di keluarkan oleh Kepala Desa Watalara tanggal 02 Februari 2017;

3) Bahwa Pemohon mengajukan penetapan ahli waris kepada Pengadilan Agama Kolaka adalah untuk mengurus harta peninggalan almarhum Nokke bin Taibe.

Berdasarkan pada Permohonan Para ahli waris dan bukti-bukti surat dan keterangan saksi di Pengadilan maka pada Tanggal 17 April 2017 Pengadilan Agama Kolaka Kelas II menetapkan ahli waris dari Nokke bin Taibe, sebagai berikut:

1) Sitti Aminah binti Lambaga (istri); 
2) Hj. Mariati binti Nokke (anak kandung);

3) Abbas bin Nokke (anak kandung);

4) Marhaeni binti Nokke (anak kandung);

5) H. Muh. Aliyas Nokke bin Nokke (anak kandung);

6) Hj. Mardania binti Nokke (anak kandung);

7) H. Muh. Amin bin Nokke (anak kandung).

Berdasarkan Penetapan Pengadilan Agama Kolaka Kelas II Nomor 0021/Pdt.P/2017/PA Klk, Para Pemohon mengajukan gugatan kepada:

1) Istri dan anak almarhum Muh. Aliyas Nokke dalam hal ini Kasma binti Buhari (Istri) dan Muh. Alfian Karamullah bin. Muhammad Aliyas Nokke (Anak).

2) Kepala Desa Watalara, Kecamatan Baula karena telah menerbitkan surat keterangan kepada Muh. Aliyas Nokke sebagai pewaris dari Nokke tanpa menyebut nama ahli waris lain yakni Para Penggugat yang juga adalah anak kandung dari Nokke bin Taibe.

3) Kepala Kantor badan Pertanahan Nasional Kabupaten Kolaka, karena telah menerbitkan perubahan balik nama sertifikat dari Nokke menjadi Muh. Aliyas Nokke tanpa melakukan klarifikasi dengan para penggugat terkait status tanah yang menjadi objek sengketa.

Menimbang Surat Keterangan Ahli Waris Nomor 470/140/DW/2013 tanggal 1 Mei 2013 yang di keluarkan Kepala Desa Watalara, telah di pergunakan oleh Muh. Aliyas Nokke dalam mengurus balik nama Sertifikat Hak Milik Nomor 210, tanpa sepengetahuan Para Penggugat sebagai Ahli Waris lainnya dari Nokke, dari sebelumnya bernama Nokke menjadi Muh. Aliyas Nokke.

Menimbang, bahwa Muh. Aliyas Nokke telah meninggal dunia, maka gugatan ini diajukan kepada Istrinya Muh. Aliyas Nokke yang bernama Hj. Kasma (Tergugat I) dan anaknya yang bernama Muh. Alfian Karanullah (Tergugat II).

Perbuatan melawan hukum atau onrechtmatige daad, menurut Pasal 1365 KUHPerdata perbuatan melawan hukum adalah perbuatan yang dilakukan oleh seseorang karena salahnya telah menimbulkan kerugian bagi orang lain. Unsur esensial dalam perbuatan melawan hukum meliputi: adanya satu perbuatan, perbuatan tersebut melawan hukum, adanya kesalahan pihak pelaku, adanya kerugian pihak korban, adanya hubungan kausal antara perbuatan dengan kerugian. Suatu perbuatan dapat dinyatakan sebagai perbuatan melawan hukum apabila: 
1) Ada perbuatan yang melanggar undang-undang yang berlaku;

2) Yang dilanggar adalah hak yang dijamin oleh hukum atau;

3) Perbuatan yang dilakukan bertentangan dengan kewajiban hukum yang seharusnya dilakukan oleh pelaku;

4) melakukan perbuatan yang bertentangan dengan kesusilaan (geode zeden);

5) Perbuatan yang bertentangan dengan sikap baik dalam bermasyarakat untuk memperhatikan kepentingan orang lain (indruist tegen de zorgvuldigheid, welke in het maatschappelijk vekeer betaamten aanzien van ander person of goed).

Menimbang bahwa setelah Majelis Hakim mencermati gugatan Para Penggugat, ternyata bukanlah gugatan yang menyangkut pembagian warisan, tetapi menyangkut Perbuatan Melawan Hukum yang dilakukan salah satu saudara Para Penggugat, yang semasa hidupnya telah mengubah/membalik Sertifikat Hak Milik Nomor 210 atas nama Nokke, tanpa persetujuan dan sepengetahuan dari Para Penggugat sebagai ahli waris lain dari Nokke dan Para Penggugat ingin mengembalikan Sertifikat Hak Milik Nomor 210 yang telah diubah untuk dijadikan sebagai bundel waris milik Para Penggugat atau harta waris milik Para Penggugat dari orang tuanya Nokke.

Putusan mengabulkan gugatan Para Penggugat untuk sebagian dan menyatakan tindakan Muh. Aliyas Nokke yang telah mempergunakan Surat Keterangan Ahli waris Nomor. 470/140/DW/2013 tanggal 1 Mei 2013, semasa hidupnya untuk mengurus balik nama Sertifikat Hak Milik Nomor 210 dari Nokke menjadi Muh. Aliyas Nokke pada Kepala Kantor Badan Pertanahan Nasional Kabupaten Kolaka, tanpa sepengetahuan dan persetujuan Para Penggugat sebagai ahli waris lainya dari Nokke adalah merupakan Perbuatan Melawan Hukum.

Putusan juga menetapkan bahwa Surat Keterangan Ahli Waris Nomor. 470/140/DW/2013 tanggal 1 Mei 2013 yang di keluarkan oleh Kepala Desa Watalara adalah bertentangan dengan bukti di persidangan. Oleh karena itu menurut Majelis Hakim tindakan yang dilakukan oleh Kepala Desa Watalara yang telah mengeluarkan Surat Keterangan Ahli Waris Nomor. 470/140/DW/2013 adalah merupakan Perbuatan Melawan Hukum.

Putusan menyatakan balik nama atas nama Muh. Aliyas Nokke terhadap Sertifikat Hak Milik Nomor 210 adalah tidak sah dan tidak mempunyai kekuatan hukum mengikat dan Sertifikat Hak Milik Nomor 210 atas nama Nokke tetap berlaku dan memiliki kekuatan 
hukum mengikat dan sita jaminan yang diletakkan oleh Pengadilan Negeri Kolaka atas obyek sengketa adalah sah dan berharga.

\section{Perlindungan Hukum bagi Ahli Waris terhadap Pengalihan Hak atas Harta Warisan Sertifikat Hak Milik Nomor 210}

Sertifikat seharusnya dapat dipahami sebagai alat bukti kepemilikan hak atas tanah yang tidak dapat diganggu gugat lagi. Sebab, sertifikat merupakan produk dari lembaga pemerintah yang berwenang atas kepemilikan tanah yakni Badan Pertanahan Nasional. Akan tetapi sebagaimana penjelasan pasal 32 Ayat (1) PP No. 24 Tahun 1997 sertifikat merupakan tanda bukti yang kuat selama tidak dapat dibuktikan sebaliknya data fisik dan data yuridis yang tercantum di dalamnya diterima sebagai data yang benar. Ini dapat disimpulkan bahwa sertifikat sebagai produk lembaga pemerintah ada kemungkinan tidak benar (terlepas dari sebab-sebabnya), dengan demikian dapat mengurangi arti kepastian hukum sertifikat itu sendiri. Ketentuan pasal 32 Ayat (1) PP No. 24 Tahun 1997 tersebut rawan menimbulkan sengketa karena sertifikat sebagai tanda bukti hak atas tanah belum dapat menjamin kebenarannya.

Ketentuan kewenangan pemerintah untuk mengatur bidang pertanahan mengakar pada pasal 33 Ayat (3) Undang-Undang 1945 yang menegaskan bahwa bumi, air dan kekayaan alam yang terkandung di dalamnya dikuasai oleh negara untuk dipergunakan bagi sebesar-besarnya kemakmuran rakyat kemudian dikukuhkan dalam Undang-Undang No. 5 Tahun 1960 tentang Peraturan Dasar Pokok-Pokok Agraria (lembaran Negara 1960-104) atau disebut juga Undang-Undang Pokok Agraria (UUPA). Selanjutnya dapat dilihat di berbagai peraturan Pemerintah, Keputusan Presiden, Peraturan Presiden, dan peraturan yang diterbitkan oleh pimpinan Instansi teknis di bidang pertanahan.

Sebagai landasan teknis pendaftaran tanah diatur dalam Peraturan Pemerintah No.

10 Tahun 1961 tantang pendaftaran tanah, kemudian disempurnakan dalam Peraturan Pemerintah No. 24 Tahun 1997. Dalam Peraturan Pemerintah Nomor 24 Tahun1997 yang merupakan penyempurnaan dari Peraturan Pemerintah No. 10 Tahun 1961, tetap dipertahankan tujuan dan sistem yang digunakan selama ini yang pada hakikatnya sudah ditetapkan dalam UUPA, yaitu bahwa pendaftaran tanah diselenggarakan dalam rangka memberikan jaminan kepastian hukum dalam penguasaan dan penggunaan tanah. Hal yang lebih penting lagi adalah menyangkut sistem pendaftaran tanah yang dikembangkan terutama menyangkut sistim publikasinya yang tetap menggunakan sistim negatif tetapi 
yang mengandung unsur positif, tidak menganut asas negatif semata dan bukan pula positif murni, karena dengan pendaftaran tanah hanya akan menghasilkan surat-surat tanda bukti hak yang berlaku sebagai alat pembuktian yang kuat seperti yang telah dinyatakan dalam pasal 19 Ayat (2) huruf c, Pasal 23 Ayat (2), Pasal 32 Ayat (2) dan pasal 38 Ayat (2).

Kewenangan pemerintah dalam mengatur bidang pertanahan terutama dalam lalu lintas hukum dan pemanfaatan tanah didasarkan pada ketentuan pasal 2 Ayat (2) UUPA yakni dalam hal kewenangan untuk mengatur dan menyelenggarakan peruntukan, penggunaan, persediaan dan pemeliharaan tanah termasuk menentukan dan mengatur hubungan-hubungan hukum antara orang-orang dengan tanah dan juga menentukan dan mengatur hubungan-hubungan hukum antara orang-orang dengan perbuatan-perbuatan hukum yang mengenai tanah. Atas dasar kewenangan tersebut maka berdasarkan pasal 4 UUPA ditentukan adanya macam-macam hak atas tanah yang dapat diberikan oleh Negara (pemerintah) kepada dan dipunyai oleh subyek hukum. Hak-hak atas tanah yang diberikan kepada subyek hukum yaitu orang atau badan hukum yang dipersamakan dengan orang adalah hak-hak atas tanah yang bersifat keperdataan sebagaimana diatur dalam pasal 16 UUPA.

Pasal 32 Ayat (2) Peraturan Pemerintah No. 24 Tahun 1997 menyatakan: Dalam hal atas suatu bidang tanah sudah diterbitkan sertifikat secara sah atas nama orang atau badan hukum yang memperoleh tanah tersebut dengan itikad baik dan secara nyata menguasainya, maka pihak lain yang merasa mempunyai hak atas tanah itu tidak dapat lagi menuntut pelaksanaan hak tersebut apabila dalam waktu 5 (lima) tahun sejak diterbitkannya sertifikat itu telah tidak mengajukan keberatan secara tertulis kepada pemegang sertifikat dan kepala kantor pertanahan yang bersangkutan ataupun tidak mengajukan gugatan ke Pengadilan mengenai penguasaan tanah atau penerbitan sertifikat tersebut.

Selain itu dari ketentuan-ketentuan mengenai prosedur pengumpulan, pengolahan, penyimpanan dan penyajian data fisik dan data yuridis serta penerbitan sertifikat dalam Peraturan Pemerintah ini tampak jelas usaha untuk sejauh mungkin memperoleh dan menyajikan data yang benar, karena pendaftaran tanah adalah untuk menjamin kepastian hukum.

Berkaitan dengan sifat pembuktian sertifikat sebagai tanda bukti hak sebagaimana ditetapkan dalam Pasal 32 Ayat (2) Peraturan Pemerintah No. 24 Tahun 1997, bahwa apabila selama 5 (lima) tahun pemegang hak atas tanah semula lalai untuk menggunakan 
tanahnya sesuai dengan sifat dan tujuan haknya, serta membiarkan hak atas tanahnya dikuasai dan didaftarkan oleh pihak lain yang beretika baik dan ia tidak mengajukan gugatan ke pengadilan, berarti yang bersangkutan menelantarkan tanahnya dan kehilangan haknya untuk menggugat. Konsepsi ini didasarkan pada lembaga rechtverwerking yang dikenal dalam hukum adat. Konsep rechtverwerking dalam pasal 32 Ayat (2) Peraturan Pemerintah No.24 Tahun 1997 ini bertujuan memberikan kepastian hukum kepada 2 (dua) pihak, yaitu:

a) Bagi pemilik sertifikat, jika sudah lewat 5 (lima) tahun sejak diterbitkan sertifikat oleh Kantor Pertanahan Kabupaten/Kodya tidak ada yang mengajukan gugatan, maka ia terbebas dari gangguan pihak lain yang merasa sebagai pemilik tanah tersebut.

b) Bagi tanah yang sebenarnya, ia wajib menguasai tanah secara nyata dan mendaftarkan tanahnya ke Kantor Pertanahan Kabupaten/Kota setempat agar terhindar dari kemungkinan tanahnya didaftarkan atas nama orang lain.

\section{Perlindungan hukum berdasarkan Putusan Pengadilan Negeri Kolaka Nomor 17/Pdt.G/PN Kka}

Dalam Pasal 32 Ayat (2) Peraturan Pemerintah No. 24 Tahun 1997 menyatakan:

"Dalam hal atas suatu bidang tanah sudah diterbitkan sertifikat secara sah atas nama orang atau badan hukum yang memperoleh tanah tersebut dengan itikad baik dan secara nyata menguasainya, maka pihak lain yang merasa mempunyai hak atas tanah itu tidak dapat lagi menuntut pelaksanaan hak tersebut apabila dalam waktu 5 (lima) tahun sejak diterbitkannya sertifikat itu telah tidak mengajukan keberatan secara tertulis kepada pemegang sertifikat dan kepala kantor pertanahan yang bersangkutan ataupun tidak mengajukan gugatan ke Pengadilan mengenai penguasaan tanah atau penerbitan sertifikat tersebut"

Meskipun unsur-unsur dalam pasal 32 Ayat (2) Peraturan Pemerintah No. 24

Tahun 1997 terpenuhi, namun orang yang merasa dirugikan atas diterbitkannya sertifikat dan untuk menyelesaikan sengketa terkait dengan diterbitkannya hak atas tanah oleh Kantor Badan Pertanahan Kabupaten/Kota, maka pihak yang merasa dirugikan dapat mengajukan gugatan ke Pengadilan.

Para tergugat dalam kasus ini adalah istri dan anak dari Muh. Aliyas Nokke yang juga adalah saudara dari Para Penggugat, yang telah melakukan balik nama Sertifikat Hak Milik Nomor 210 atas nama Nokke orang tua dari Para Penggugat dan Muh. Aliyas Nokke.

Berdasarkan bukti surat dan keterangan saksi-saksi dalam persidangan, salah satunya saksi Parerungan, bahwa Surat Keterangan Ahli Waris Nomor: 470/140/DW/2013, tertanggal 1 Mei 2013 adalah tidak ada dalam agenda surat dan tidak sesuai dengan Nomor 
Surat Ahli Waris Tanah, sebab nomor surat yang dipakai adalah Kode Nomor Surat Kependudukan, yang semestinya menggunakan kode 590. Maka Majelis Hakim menyatakan bahwa "sita jaminan yang diletakkan oleh Pengadilan Negeri Kolaka atas objek sengketa adalah sah dan berharga" dan Sertifikat hak Milik atas nama Nokke tetap berlaku dan memiliki kekuatan hukum mengikat dan menurut Majelis Hakim petitum Para Penggugat tersebut beralasan hukum, maka petitum tersebut patut di kabulkan.

Kasus tersebut memberikan gambaran bahwa hukum memberikan perlindungan bagi para pihak yang hak penerimaan warisannya dikaburkan oleh pihak lain. Meski telah diterbitkan sertifikat oleh Kantor Badan Pertanahan Nasional, tapi dengan mengajukan gugatan dan dengan bukti-bukti yang kuat maka sertifikat Pewaris dapat di pulihkan kembali.

Dalam menyelesaikan segala permasalahan hukum termasuk sengketa tanah warisan yang kepemilikannya beralih tanpa persetujuan sebagian Ahli Waris lainnya, peran pengadilan sangat penting untuk menciptakan kepastian hukum dan memberikan rasa adil bagi para pihak yang berperkara.

Pengadilan merupakan penentu siapa pemilik tanah hak milik yang sesungguhnya dari tanah yang diperkarakan, sesuai pendapat Karl Llewellyn bahwa What Officiallls Do About Disputes is the Law it Self (atau apa yang diputuskan oleh para Hakim tentang suatu persengketaan adalah hukum itu sendiri).13

\section{KESIMPULAN}

Dari uraian yang disebutkan dalam pembahasan, maka dapat ditarik kesimpulan sebagai berikut: Pengalihan hak kepemilikan atas harta warisan menurut Hukum Perdata Indonesia (BW) adalah dengan cara pembagian warisan yang diselenggarakan dengan pemufakatan atau atas kehendak bersama. Semua pihak harus mengetahui dan saling menghargai haknya masing-masing atas Harta Warisan yang merupakan harta bersama. Persetujuan Ahli Waris untuk proses pengalihan Harta Warisan adalah supaya menghindari terjadinya sengketa harta waris antara Ahli Waris. Sebab, setiap pengalihan harta warisan harus disetujui dan diketahui oleh seluruh Ahli Waris dari si Pewaris jika tidak maka pengalihan tersebut tidak sah. Hukum Perdata dan hukum yang berkaitan dengan Perolehan dan Pendaftaran Tanah khususnya pada Pasal 32 Ayat (2) Peraturan Pemerintah No. 24 Tahun 1997 memberikan

13 Karl Llewellyn, dalam Achmad Ali, Wiwie Heryani, Menjelajahi Kajian Empiris terhadap Hukum, Jakarta: Kencana, 2012, hlm. 104. 
peluang bagi pihak yang merasa dirugikan atas diterbitkannya sertifikat dan untuk menyelesaikan sengketa terkait dengan diterbitkannya hak atas tanah oleh Kantor Badan Pertanahan Kabupaten/Kota, maka pihak yang merasa dirugikan dapat mengajukan gugatan ke Pengadilan. Sebagaimana yang telah dilakukan oleh Para Penggugat pada kasus penerbitan balik nama Sertifikat Hak Milik Nomor 210. Sebagai upaya untuk membela hak para pihak yang tidak mengetahui atau diminta persetujuan pada proses balik nama sertifikat Hak Milik yang merupakan Harta Warisan. Putusan Pengadilan Negeri Kolaka Nomor 17/Pdt.G/2017/Pn Kka, telah memberikan perlindungan hukum dan kepastian hukum, yaitu dengan mengabulkan gugatan Para Penggugat agar Sertifikat Hak Milik Nomor 210 yang telah di alihkan tanpa meminta persetujuan seluruh Ahli Waris dari Nokke menjadi Muh. Aliyas Nokke di pulihkan kembali dengan menyatakan bahwa sertifikat atas nama Muh. Aliyas Nokke adalah tidak sah dan tidak memiliki kekuatan mengikat. Serta, sertifikat atas nama Nokke adalah sah dan memiliki kekuatan mengikat.

\section{Daftar Pustaka}

\section{Buku}

Ali, Achmad, Wiwie Heryani, Menjelajahi Kajian Empiris terhadap Hukum, Jakarta: Kencana, 2012.

Hadikusuma, H. Hilman, Hukum Waris Adat, Bandung: PT. Citra Bakti, 2003.

Marzuki, Peter Mahmud, Penelitian Hukum, Jakarta: Kencana Group, 2005.

R., Prodjodikoro Wiryono, Hukum Waris di Indonesia, Bandung: Sumur Bandung, 1983.

Sarwono, Jonathan, Metode Penelitian Kuantitatif dan Kualitatif, Yogyakarta: Graha Ilmu, 2006.

Sjaiful, Muhammad, Wajah Politik Hukum Indonesia, Kendari: Komunika, 2014.

Soekanto, Soerjono, Sri Mamudji, Penelitian Normatif, UII Perss, Jakarta: 2001.

Sofyan, Syahril, Beberapa Dasar Teknik Pembuatan Akta (Khusus Warisan), Medan: Pustaka Bangsa Press, 2011.

Suparman, Maman, Hukum Waris Perdata, Jakarta: Sinar Grafika, 2015.

Surojo, Wignjodipuro, Pengantar dan Azas-Azas Hukum Adat, Bandung: Alumni, 1973.

Sutedi, Adrian, Sertifikat Hak Atas Tanah, Jakarta: Sinar Grafika, 2011.

Yamin, Muhammad, Beberapa Dimensi Filosofi hukum Agraria, Medan, Pustaka Bangsa Perss, 2003. 